\title{
Optimization and characterization of biosurfactant production from marine Vibrio sp. strain 3B-2
}

\author{
Xiaoke $\mathrm{Hu}^{1 *}$, Caixia Wang ${ }^{1,2}$ and Peng Wang ${ }^{3}$ \\ ${ }^{1}$ Key Laboratory of Coastal Biology and Bioresource Utilization, Yantai Institute of Coastal Zone Research, Chinese \\ Academy of Sciences, Yantai, China, ${ }^{2}$ University of Chinese Academy of Sciences, Beijing, China, ${ }^{3}$ Ocean University of \\ China, Qingdao, China
}

\section{OPEN ACCESS}

Edited by:

Cheng Zhong,

Tianjin University of Science and Technology, China

Reviewed by:

Vidya De Gannes,

The University of the West Indies,

Trinidad and Tobago

Bharath Prithiviraj,

The Samuel Roberts Noble

Foundation, USA

${ }^{*}$ Correspondence:

Xiaoke $\mathrm{Hu}$,

Key Laboratory of Coastal Biology and Bioresource Utilization, Yantai Institute of Coastal Zone Research,

Chinese Academy of Sciences, Chunhui Road, Yantai 264003, China xkhu@yic.ac.cn

Specialty section:

This article was submitted to Microbiotechnology, Ecotoxicology and Bioremediation

a section of the journal

Frontiers in Microbiology

Received: 18 June 2015 Accepted: 02 September 2015 Published: 23 September 2015

Citation:

Hu X, Wang C and Wang P (2015) Optimization and characterization of biosurfactant production from marine Vibrio sp. strain 3B-2.

Front. Microbiol. 6:976. doi: 10.3389/fmicb.2015.00976
A biosurfactant-producing bacterium, designated 3B-2, was isolated from marine sediment and identified as Vibrio sp. by $16 \mathrm{~S}$ rRNA gene sequencing. The culture medium composition was optimized to increase the capability of 3B-2 for producing biosurfactant. The produced biosurfactant was characterized in terms of protein concentration, surface tension, and oil-displacement efficiency. The optimal medium for biosurfactant production contained: $0.5 \%$ lactose, $1.1 \%$ yeast extract, $2 \%$ sodium chloride, and $0.1 \%$ disodium hydrogen phosphate. Under optimal conditions $\left(28^{\circ} \mathrm{C}\right)$, the surface tension of crude biosurfactant could be reduced to 41 from $71.5 \mathrm{mN} / \mathrm{m}$ (water), while its protein concentration was increased to up to $6.5 \mathrm{~g} / \mathrm{L}$ and the oil displacement efficiency was improved dramatically at $6.5 \mathrm{~cm}$. Two glycoprotein fractions with the molecular masses of 22 and $40 \mathrm{kDa}$ were purified from the biosurfactant, which held great potential for applications in microbial enhanced oil recovery and bioremediation.

Keywords: microbial biosurfactant, optimal production, surface tension, Vibrio alginolyticus, glycoproteins

\section{Introduction}

Oil contamination is a common problem in tanker spills and drilling rig blowouts, which seriously impacts the ecological balance of marine ecosystems (Jernelöv, 2010). Traditional remediation deals with oil contamination by chemical and physical means. Chemical remediation involves the use of chemical compounds as oxidant, reductant, polymer, and/or precipitant (Xue et al., 2015). Physical remediation removes residual oil using adsorbent (Daifullah and Girgis, 2003). The chemical and physical methods are expensive and complex operational, leaving non-biodegradable residues potentially toxic to the environment (Makkar and Cameotra, 2002). Bioremediation uses naturally occurring microorganisms to degrade contaminants and this biological means has been proved to be effective for removing oil contaminants (Rathore et al., 2013).

Hydrocarbons have low solubility and high hydrophobicity, and thus are often unavailable to microorganisms. Biosurfactant-producing microorganisms such as Pseudomonas aeruginosa are capable of degrading hydrocarbons and use them as carbon sources (Zhang et al., 2012). Another example is Vibrio sp. P-2P44T utilizing polycyclic aromatic hydrocarbons as substrate, such as naphthalene, 2-methylnaphthalene, and phenanthrene (Hedlund and Staley, 2001). Biosurfactants are amphipathic molecules consisting of both hydrophilic and hydrophobic moieties. Such 
compounds are composed of different biological macromolecules (e.g., lipid, phospholipid, polysaccharide, and protein) and contain various functional groups (e.g., carboxyl, amino, and phosphate; Desai and Banat, 1997).

Surfactants possess functional properties such as detergency, emulsification, foaming, and dispersion (Lee et al., 2008). Microorganisms produce a variety of surfactants, including lowmolecular-weight polymers that can efficiently reduce surface and interfacial tension, and high-molecular-weight molecules that act as highly efficient emulsifiers (Toledo et al., 2008). Compared with chemical surfactants, biosurfactants exhibit the advantages of mild production condition, lower toxicity, higher biodegradability, and environmental compatibility (Makkar and Cameotra, 2002). Biosurfactants hold great potential for applications in the environmental protection as well as in the food, cosmetic, biopesticide, and pharmaceutical industries (Singh and Cameotra, 2004).

Thus far, only a few biosurfactants have been produced at large scale for commercial applications, mainly because of their considerable costs of production and recovery (Shete et al., 2006). The controlling parameters of biosurfactant production are required to be maintained within a certain range of operating conditions whereby the activity of bacteria with the resultant maximum production of biosurfactant can be optimized. In this regard, temperature, $\mathrm{pH}$, medium composition, and salinity are of prime importance for controlling and optimizing biosurfactant production (Najafi et al., 2010). Pseudomonas, Candida, and Rhodococcus have been studied extensively regarding surfactant biosynthesis (Singh et al., 1990; Espuny et al., 1996). Currently, relative little information is available on the optimal conditions for biosurfactant production from Vibrio species.

If maintained under optimal conditions for growth and activity, that biosurfactant producer can only be improved. Response surface methodology (RSM) is one of the best methods to design the optimization experiments (Wei et al., 1998). RSM comprises a set of statistical techniques, which aims to build models, evaluate the effects of operating factors and search for the optimal conditions using design of experiments (Rodrigues et al., 2006). The analytical hierarchy process (AHP) is a technique for organizing the information and judgment used in making complex decisions. The AHP can solve especially where multiple factors and choices (or alternatives) have to be considered simultaneously (Mansora et al., 2013). Application of the AHP has been noted in different industries such as investment appraisal (Hedlund and Staley, 2001), project selection and human resource evaluation. No study has reported the use of the AHP in medium optimization.

In this study, a biosurfactant-producing Vibrio strain, designated 3B-2, was isolated from marine sediment. The objectives of this study were: (1) to identify the physical and chemical factors affecting biosurfactant production from strain $3 \mathrm{~B}-2$, and (2) to find the optimal composition of growth medium for flask-scale biosurfactant production using the RSM and AHP techniques. The results may provide hints at potential applications of biosurfactant from marine Vibrio in environmental, biomedical and agricultural fields.

\section{Materials and Methods}

\section{Isolation and Characterization of Biosurfactant-Producing Bacteria}

Fresh sediment samples (10 g) and crude oil (1 g) were coincubated in $100 \mathrm{~mL}$ of mineral medium in darkness for 7 days, with shaking at $180 \mathrm{rpm}$ at $30^{\circ} \mathrm{C}$. The mineral medium contained: $7.01 \mathrm{mM} \mathrm{K} \mathrm{HPO}_{4}, 2.94 \mathrm{mM} \mathrm{KH} \mathrm{PO}_{4}, 0.81 \mathrm{mM}$ $\mathrm{MgSO}_{4} \cdot 7 \mathrm{H}_{2} \mathrm{O}, 0.18 \mathrm{mM} \mathrm{CaCl}_{2}$, and $1.71 \mathrm{mM} \mathrm{NaCl}$ (Lin et al., 2014). The $\mathrm{pH}$ of the medium was adjusted to 7.0 using $1 \mathrm{M}$ $\mathrm{NaOH}$. Crude oil used in this study was obtained from the Shengli Oil Field, Dongying, Shandong, China, and sediment was collected from the Bohai Bay, an area adjacent to Penglai 19-3 oil platform $\left(120^{\circ} 01^{\prime} \sim 120^{\circ} 08^{\prime} \mathrm{E}, 38^{\circ} 17^{\prime} \sim 38^{\circ} 27^{\prime} \mathrm{N}\right)$, which were kindly supplied by the North China Sea Branch of The State Oceanic Administration. For both sediment and oil samples, we collected three tubes ( $\sim 50 \mathrm{~g})$ from different positions of a bucket to form a composite sample. To isolate bacterial strains, zero point one-milliliter aliquots of the sediment culture were aseptically spread onto Marine Agar 2216E plates (Difco, USA). The inoculated plates were incubated at $30^{\circ} \mathrm{C}$ for $48 \mathrm{~h}$. Morphologically distinct colonies were obtained by repetitive streaking five times onto $2216 \mathrm{E}$ plates.

Surface tension and the diameter of clear zone on the oil surface were measured to evaluate the production of biosurfactant and screen the isolates of interest. The lower the surface tension, the better the biosurfactant; the diameter of clear zone depends on the concentration of the biosurfactant (Youssef et al., 2004). A strain with rapid growth and higher biosurfactant production was selected and named 3B-2. Purified culture samples of 3B-2 were dispensed into cryovials, added with $15 \%$ glycerol, and preserved at $-20^{\circ} \mathrm{C}$ immediately. Strain $3 \mathrm{~B}-2$ was examined by morphological observations which the Gram staining was tested with photomicroscopy, morphological trait of the isolated strain was observed under a scanning electron microscope. Phenotypic analysis and various biochemical tests were carried out by following what was described in Bergey's Manual of Systematic Bacteriology (Noel and George, 2005).

\section{S rDNA Sequencing}

Bacterial genomic DNA was extracted using a DNA extraction kit (Sigma, USA) following the manufacturer's instructions. PCR amplification of bacterial 16S rDNA was performed using universal primers 27F $\left(5^{\prime}\right.$-AGAGTTTGATCMTGGCTCAG-3') and 1492R ( $5^{\prime}$-CGGYTACCTTGTTACGACTT-3') as previously described (Enticknap et al., 2006). The PCR product of $16 \mathrm{~S}$ rDNA from strain 3B-2 (1119 bp) was directly sequenced by Sangon Biotech (Shanghai) Co., Ltd. The obtained sequence was compared using the BLAST Tool of $\mathrm{NCBI}^{1}$. Closely related sequences were retrieved from the GenBank database and sequence alignment was performed using ClustalW v2.0. Phylogenetic tree was constructed using the maximum-likelihood algorithm in MEAG v5.02.

\footnotetext{
${ }^{1}$ http://www.ncbi.nlm.nih.gov

${ }^{2}$ www.megasoftware.net
} 


\section{Biosurfactant Production and Purification}

Strain 3B-2 was transferred into $5 \mathrm{~mL}$ of modified Marine Broth $2216 \mathrm{E}(0.1 \%$ yeast extract, $0.5 \%$ peptone, and $1.5 \% \mathrm{NaCl})$ and incubated for $24 \mathrm{~h}\left(32^{\circ} \mathrm{C}, 180 \mathrm{rpm}\right)$ to obtain the seed culture. Then $5 \mathrm{~mL}$ of culture suspensions were transferred to a 250 $\mathrm{ml}$ Erlenmeyer flask containing $100 \mathrm{~mL}$ of modified 2216E. The culture was incubated with shaking at $180 \mathrm{rpm}, 32^{\circ} \mathrm{C}$ for $48 \mathrm{~h}$. Thereafter, the supernatant was removed from the culture broth by centrifugation at $8,000 \mathrm{rpm}, 4^{\circ} \mathrm{C}$ for $10 \mathrm{~min}$. The collected cells were re-suspended in $10 \mathrm{~mL}$ of distilled water and crude biosurfactant was extracted using an ultrasonic cell disintegrator (JY 92-IID, Xinzhi Biotech., Ningbo, China). The extraction conditions were as follows: amplitude transformer $\Phi 10$, power $70 \%$ and extraction time $30 \mathrm{~min}$. Then the ultrasonic extract was centrifuged at $7000 \mathrm{rpm}$ for $10 \mathrm{~min}$ at $4^{\circ} \mathrm{C}$. The supernatant was used as the crude biosurfactant and preserved at $-20^{\circ} \mathrm{C}$ before analysis.

The AKTA protein purification system was used to purify crude biosurfactant. The sample was applied to a HiPrep DEAE-FF column $(1.0 \mathrm{~cm} \times 1.0 \mathrm{~cm})$ pre-equilibrated with ultra-pure water (mobile phase $\mathrm{A}$ ), and then eluted using a gradient of buffer from 0 to $1 \mathrm{M}(1 \mathrm{M} \mathrm{NaCl}$, mobile phase B) at a flow rate of $1.0 \mathrm{~mL} / \mathrm{min}$. Proteins were detected at $280 \mathrm{~nm}$. Fractions exhibiting oil-displacement activity were pooled, concentrated, and injected into a Sephrcryl S-100 HR column $(1.0 \mathrm{~cm} \times 80 \mathrm{~cm})$ equilibrated with ultra-pure water at $0.3 \mathrm{~mL} / \mathrm{min}$. Further, fractions were collected and screened for oil-displacement activity.

\section{Analytical Methods Biomass Estimation}

Biomass was monitored by spectrophotometry (Martinez et al., 2000). The optical density (OD) of culture samples at $600 \mathrm{~nm}$ wavelength was measured and the blank medium was adjusted to $\mathrm{OD}_{600}=0$.

\section{Protein Concentration}

The protein level of crude biosurfactant was determined using Lowry's method (Lowry et al., 1951) with bovine serum albumin (Sigma, America) as a protein standard.

\section{Surface Tension Measurement}

The surface tension of crude biosurfactant was measured using a digital surface tensiometer (BZY-201, Fangrui, Shanghai, China) by the Du Nüoy ring method (Santos et al., 2014). Briefly, $10 \mathrm{~mL}$ of samples were transferred into a clean plate and placed on the tensionmeter platform. A platinum strip was slowly put on the liquid-air interface to measure surface tension $(\mathrm{mN} / \mathrm{m})$. The platinum strip was washed (with chromic acid, ultrapure water, and acetone), flamed and dried between each measurement. Calibration was performed using ultrapure distilled water (surface tension $=71.5 \pm 0.5 \mathrm{mN} / \mathrm{m}$ ) before sample measurement.

\section{Oil Displacement Test}

The procedure of oil displacement test for surfactants was slightly modified from a previously reported method (Morikawa et al.,
1993). Firstly, $1 \mathrm{~g}$ of crude oil (Shengli Oil Field) was dissolved in $20 \mathrm{~mL}$ of chloroform to obtain an oil solution. Secondly, $2 \mathrm{~mL}$ of oil solution was put onto the surface of $20 \mathrm{~mL}$ of distilled water in a $15-\mathrm{cm}$ diameter Petri dish to form a thin membrane of oil. Then, $40 \mu \mathrm{L}$ of crude biosurfactant was put on the center of the oil membrane. A clear zone was visible immediately on the oil surface and the diameter was measured to calculate oil displacement.

\section{Optimization Procedure of Biosurfactant Production Physical Parameters}

One loopful of bacterial culture from the preliminary slant medium was transferred aseptically to shake flask medium and incubated for $24 \mathrm{~h}\left(80 \mathrm{rpm}, 32^{\circ} \mathrm{C}\right)$ to obtain the seed culture. The seed was inoculated into Modified Marine Broth $2216 \mathrm{E}$ and incubated on a $180-\mathrm{rpm}$ rotary shaker at different temperatures $\left(25,28,31,34\right.$, and $\left.37^{\circ} \mathrm{C}\right)$. The effects of broth content $(50,75,100$, and $125 \mathrm{~mL})$ and inoculum size $(4,6$, 8 , and $10 \%$ ) on biosurfactant production from strain 3B-2 were also studied. Biosurfactant production was evaluated using four indices described in Section "Optimization Procedure of Biosurfactant Production."

\section{Carbon and Nitrogen Sources}

Strain 3B-2 was grown in Modified Marine Broth 2216E supplemented with different carbon sources $(1 \%, \mathrm{w} / \mathrm{v})$, including glucose, sucrose, lactose, maltose, and xylose. The effect of different nitrogen sources on biosurfactant production was also studied, including beef extract, peptone, yeast extraction, soybean meal, and corn meal (organic; 0.5\%, w/v) and $\left(\mathrm{NH}_{4}\right)_{2} \mathrm{SO}_{4}, \mathrm{NH}_{4} \mathrm{NO}_{3}, \mathrm{NH}_{4} \mathrm{Cl}, \mathrm{NaNO}_{3}$, and urea (inorganic; $0.3 \%, \mathrm{w} / \mathrm{v})$.

\section{Salinity and lons}

On the basis of optimal carbon and nitrogen sources, different concentrations of $\mathrm{NaCl}(0,5,10,15,20$, and $30 \mathrm{~g} / \mathrm{L})$ were added into Modified Marine Broth 2216E. Additionally, different ions $\left(0.05 \%\right.$, w/v) including $\mathrm{ZnSO}_{4}, \mathrm{Na}_{2} \mathrm{HPO}_{4}, \mathrm{CaCl}_{2}, \mathrm{BaCl}_{2}, \mathrm{CuSO}_{4}$, $\mathrm{MgSO}_{4}, \mathrm{MnSO}_{4}$, and $\mathrm{FeCl}_{3}$ were added. The effects of salinity ( $\mathrm{NaCl}$ concentration) and ions on biosurfactant production from strain 3B-2 were studied.

\section{The AHP Method was Used as a Modeling and Optimization Tool}

Analytical hierarchy process is a multi-criteria method that can be used to evaluate the importance of each component of the medium. The AHP model consists of three levels: the top level (goal), the second level (criteria), and the third level (alternatives; Ong et al., 2001). In this study, the goal was the optimal factor; the criteria included the biomass, the protein concentration, the surface tension of biosurfactant, and the diameter of clear zone; the alternatives referred to different operating factors.

\section{Structure of the AHP model \\ Step 1}

In the AHP model, the top level (the goal) is the optimal medium composition (or operating factors). At the second level, there 


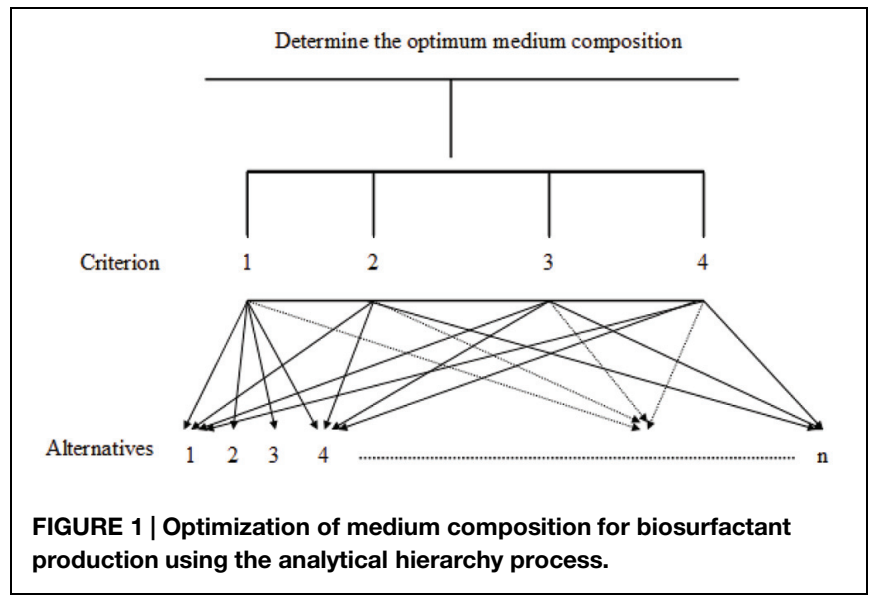

are four criteria: the biomass $\left(\mathrm{OD}_{600}\right)$, the protein concentration, the surface tension, and the diameter of clear zone. At the third level, there are $n$ alternatives that must be compared and assessed. An example of the AHP model for a case study of medium composition is shown in Figure 1.

\section{Step 2}

The judgment matrix is structured in each of the three levels. The weights of different criteria are not necessarily the same in the criterion level. The judgment matrix $A=\left(a_{i j}\right)_{n \times n}$ is defined to use discrete 9-point scales (Table 1).

Step 3

The matrix is normalized and the importance of the criteria is determined using the geometric mean algorithms. The degree of importance for the criteria is set as $w_{i}$ (Liao, 2010):

$$
W i=\frac{\left(\prod_{j=1}^{n} a i j\right)^{1 / n}}{\sum_{i=1}^{n}\left(\prod_{j=1}^{n} a i j\right)^{1 / n}} i, j=1,2, \ldots n
$$

Step 4

For single hierarchical sorting, a consistency index $(C I)$ is determined as follows:

$$
C I=\frac{\lambda_{\max }-n}{n-1}
$$

where $\lambda_{\max }$ is the maximal eigen value.

A consistency ratio $(C R)$ is expressed to check for consistency:

$$
C R=\frac{C I}{R I}
$$

where $R I$ denotes the average random index with the value (Table 2). The judgment matrix of consistency is considered reasonable for $C R<0.1$.

\section{Step 5}

The priority for all alternatives is determined and the alternative (supply chain process) with the highest overall priority weight is chosen.

\section{Optimization by RSM}

Response surface methodology was used to optimize the screening variables for enhanced biosurfactant production using
TABLE 1 | The Saaty fundamental 9-point scale for comparative judgments.

\begin{tabular}{ll}
\hline Intensity of importance & Definition \\
\hline 1 & Equal importance \\
3 & Moderate importance \\
5 & Strong importance \\
7 & Very strong importance \\
9 & Extreme importance \\
$2,4,6,8$ & For compromise between above values
\end{tabular}

TABLE 2 | The random index $(R I)$ for consistency check of the judgment matrix.

\begin{tabular}{lllllllllll}
\hline $\boldsymbol{N}$ & $\mathbf{1}$ & $\mathbf{2}$ & $\mathbf{3}$ & $\mathbf{4}$ & $\mathbf{5}$ & $\mathbf{6}$ & $\mathbf{7}$ & $\mathbf{8}$ & $\mathbf{9}$ & $\mathbf{1 0}$ \\
\hline$R l$ & 0.00 & 0.00 & 0.58 & 0.90 & 1.12 & 1.24 & 1.32 & 1.41 & 1.45 & 1.49 \\
\hline
\end{tabular}

a central composite design (CCD). The significant variables utilized were lactose, yeast extract and $\mathrm{NaCl}$, each at five coded levels $(-1.682,-1,0,+1$, and +1.682 ; Table 3 ). The response values $(Y)$ in each trial represent the overall weight.

\section{Electrophoretic Analysis}

The molecular weight of purified fractions of biosurfactant from 3B-2 was estimated using SDS-PAGE as previously described (Laemmli, 1970).

\section{Statistical Analysis}

The experiments were carried out in triplicate and data were expressed as the mean values. An analysis of variance (ANOVA) for the obtained results was performed, and $p$-values less than 0.05 were considered statistically significant. Design Expert 8.0.6 (Stat-Ease, Inc., USA) was employed for experimental design, ANOVA and process optimization.

\section{Results and Discussion}

\section{Characterization of Biosurfactant-Producing Strain 3B-2}

A total of 20 biosurfactant-producing bacterial strains were isolated from the crude oil-contaminated sediment in Bohai Bay. Among the final candidates, strain 3B-2 was selected for the highest biosurfactant production and oil-displacement activity. The biosurfactant from 3B-2 demonstrated the primary ability of oil displacement at $5.0 \mathrm{~cm}$, and its surface tension dropped below $40 \mathrm{mN} / \mathrm{m}$ in Modified Marine Broth 2216E.

Morphological observations revealed that strain 3B-2 formed round, moist, and dense colonies with smooth surface on the screening plates. Detailed biochemical characteristics of 3B-2 are shown in Table 4. 3B-2 was a Gram-negative bacterium capable of utilizing glucose, maltose and mannose. It was positive for oxidase activity but negative for $\mathrm{O} / 129$. Based on these results, strain 3B-2 was tentatively identified as a member of genus Vibrio. 
TABLE 3 | The central composite design matrix and experimental results of biosurfactant characterization.

\begin{tabular}{|c|c|c|c|c|c|c|c|c|c|}
\hline \multirow[t]{2}{*}{ Run } & \multicolumn{3}{|c|}{ Coded } & \multicolumn{4}{|c|}{ Test indices } & \multicolumn{2}{|c|}{ Weight } \\
\hline & $\begin{array}{l}X_{1} \\
\text { (lactose) }\end{array}$ & $\begin{array}{l}X_{2} \text { (yeast } \\
\text { extract) }\end{array}$ & $\begin{array}{l}X_{3} \\
(\mathrm{NaCl})\end{array}$ & $\begin{array}{l}\text { Biomass } \\
\left(O_{600}\right)\end{array}$ & $\begin{array}{l}\text { Protein } \\
\text { concentration }(\mathrm{g} / \mathrm{L})\end{array}$ & $\begin{array}{l}\text { Surface tension } \\
(\mathrm{mN} / \mathrm{m})\end{array}$ & $\begin{array}{l}\text { Diameter of } \\
\text { clear zone }(\mathrm{cm})\end{array}$ & $\begin{array}{l}\text { Actual } \\
\text { value }\end{array}$ & $\begin{array}{l}\text { Predicted } \\
\text { value }\end{array}$ \\
\hline 1 & 0 & 0 & 0 & 0.59 & 4.39 & 37.81 & 4.30 & 0.0268 & 0.0268 \\
\hline 2 & 0 & 0 & -1.682 & 0.35 & 2.65 & 49.36 & 4.50 & 0.0161 & 0.0161 \\
\hline 3 & 1 & 1 & 1 & 0.86 & 5.29 & 40.72 & 5.50 & 0.0374 & 0.0374 \\
\hline 4 & 1 & -1 & -1 & 0.29 & 2.29 & 45.69 & 4.00 & 0.0133 & 0.0133 \\
\hline 5 & -1 & 1 & -1 & 0.54 & 4.37 & 50.51 & 6.00 & 0.0304 & 0.0304 \\
\hline 6 & 1 & 1 & -1 & 0.72 & 5.09 & 47.57 & 7.00 & 0.0409 & 0.0409 \\
\hline 7 & 0 & -1.682 & 0 & 0.16 & 1.32 & 48.00 & 0.00 & -0.0134 & -0.0134 \\
\hline 8 & -1 & -1 & -1 & 0.28 & 2.02 & 48.35 & 0.00 & -0.0103 & -0.0103 \\
\hline 9 & 0 & 0 & 0 & 0.60 & 4.11 & 41.96 & 5.00 & 0.0283 & 0.0283 \\
\hline 10 & -1 & 1 & 1 & 0.85 & 5.33 & 38.25 & 7.00 & 0.0466 & 0.0466 \\
\hline 11 & 1.682 & 0 & 0 & 0.59 & 4.16 & 43.38 & 4.50 & 0.0251 & 0.0251 \\
\hline 12 & 1 & -1 & 1 & 0.37 & 2.85 & 41.47 & 4.50 & 0.0199 & 0.0199 \\
\hline 13 & 0 & 0 & 0 & 0.62 & 4.33 & 42.89 & 5.50 & 0.0315 & 0.0315 \\
\hline 14 & 0 & 1.682 & 0 & 1.00 & 6.25 & 41.36 & 6.50 & 0.0467 & 0.0467 \\
\hline 15 & 0 & 0 & 0 & 0.59 & 4.50 & 38.00 & 4.50 & 0.0289 & 0.0289 \\
\hline 16 & 0 & 0 & 0 & 0.59 & 4.50 & 38.00 & 4.50 & 0.0289 & 0.0289 \\
\hline 17 & -1 & -1 & 1 & 0.36 & 2.84 & 43.11 & 5.00 & 0.0219 & 0.0219 \\
\hline 18 & 0 & 0 & 1.682 & 0.67 & 4.38 & 37.85 & 6.00 & 0.0368 & 0.0368 \\
\hline 19 & -1.682 & 0 & 0 & 0.59 & 4.40 & 40.36 & 5.00 & 0.0296 & 0.0296 \\
\hline 20 & 0 & 0 & 0 & 0.59 & 4.50 & 38.00 & 4.50 & 0.0289 & 0.0289 \\
\hline
\end{tabular}

$O D_{600}$ is the optical density of bacterial culture at $600 \mathrm{~nm}$ wavelength.

TABLE 4 | Physiological and biochemical properties of strain 3B-2 from marine sediment in Bohai Bay, China (VITEK 2 Compact).

\begin{tabular}{llllllll}
\hline Item & Result & Item & Result & Item & Result & Item & Result \\
\hline APPA & + & ADO & - & PyrA & + & IARL & - \\
H2S & - & BNAG & + & AGLTp & - & DGLU & + \\
BGLU & - & dMAL & + & dMAN & + & dMNE & + \\
ProA & + & LIP & - & PLE & - & TyrA & + \\
SAC & + & dTAG & - & dTRE & + & CIT & - \\
ILATK & + & AGLU & - & SUCT & + & NAGA & - \\
GlyA & + & ODC & - & LDC & + & IHISA & + \\
O129R & - & GGAA & + & IMLTa & + & ELLM & + \\
dCEL & - & BGAL & - & GGT & + & OFF & + \\
BXYL & - & BALap & - & MNT & - & 5KG & - \\
URE & - & DSOR & - & AGAL & - & PHOS & + \\
CMT & + & BGUR & - & ILATa & - & & \\
& & & & & & &
\end{tabular}

\section{Identification of Biosurfactant-Producing Strain 3B-2}

Sequence alignment revealed that 3B-2 was highly related (99\% identity) to Vibrio species, such as V. parahaemolyticus strain H061 (KJ577056.1), Vibrio alginolyticus strain B174 (KC884590.1), and $V$. harveyi strain NA02 (KJ563265.1). Therefore, strain 3B-2 was identified as Vibrio sp.

A phylogenetic tree was constructed based on $16 \mathrm{~S}$ rDNA sequences of strain $3 \mathrm{~B}-2$ and its close relatives retrieved from the GenBank database (Figure 2). In the maximum-likelihood tree, 3B-2 was clustered with most known strains of Vibrio sp. The result of phylogenetic analysis agreed with those of phenotypic tests. Strain 3B-2 was named Vibrio sp. 3B-2 and deposited in the China Center for Type Culture Collection under accession number CJ11052.

\section{Optimization of Biosurfactant Production Effect of Physical Parameters}

Temperature is a critical environmental factor affecting microbial growth and reproduction (Ratkowsky et al., 1982). The effect of temperature on biosurfactant production from strain 3B-2 is shown in Table 5. In this test, the goal was the optimal temperature; the alternatives were different temperatures. The matrices were built as described in Section "The AHP Method was used as a Modeling and Optimization Tool." The $\lambda_{\max }$ values of the alternatives to the criteria were 5.26, 5.19, 5.22, and 5.22 $\left(C R=0.0585,0.043,0.0491\right.$, and 0.0481 , respectively). The $\lambda_{\max }$ value of the criteria to the goal was $4.05(C R=0.017)$ and that of the alternatives to the goal was $5.22(C R=0.0485)$. All the above $C R$ values were less than 0.1 , which passed the consistency test.

The obtained $\lambda_{\max }$ values represent the weights of individual test indices and their overall weight is given in Table 5. Results showed that the biosurfactant production from strain 3B-2 gradually increased from 25 to $28^{\circ} \mathrm{C}$ and the maximal production occurred at $28^{\circ} \mathrm{C}$. Increase in the temperature beyond $28^{\circ} \mathrm{C}$ had an adverse effect on the biosurfactant production (Table 5). It has been suggested that microorganisms synthesize only a reduced number of proteins essential for growth and other vital physiological processes at high temperatures (Gawande and Kamat, 1999). For strain 3B-2, the temperature greater than $28^{\circ} \mathrm{C}$ 


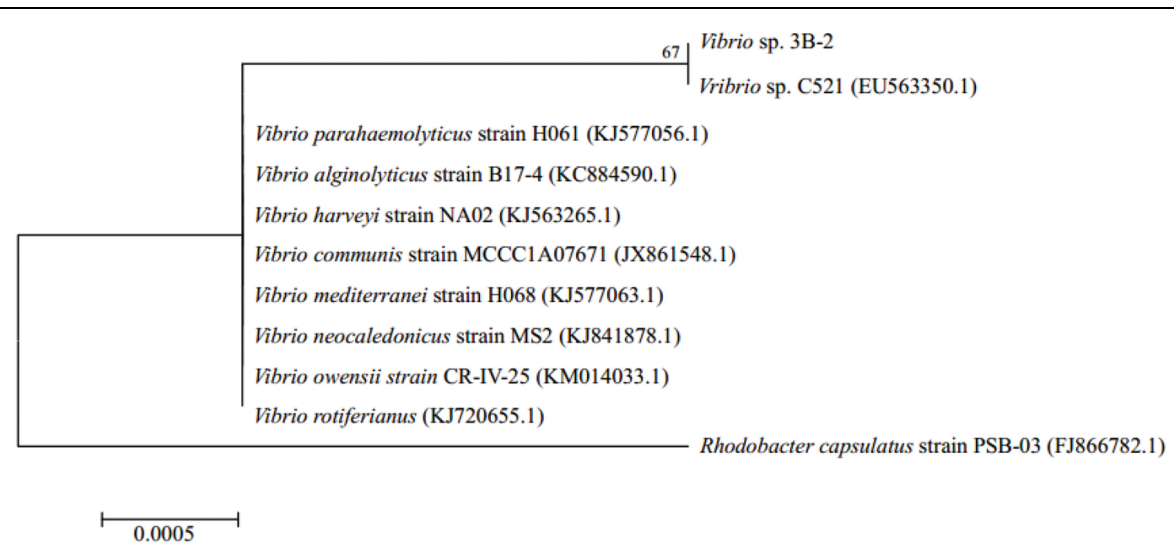

FIGURE 2 | Maximum-likelihood tree based on 16S rDNA gene sequence of strain 3B-2 isolated from Bohai Bay sediment (1169 bp) and those of known relatives retrieved from the GenBank database (accession No. in brackets). Bootstrap values shown at nodes for frequencies at or above a $50 \%$ threshold (per 1000 trials bootstrap resampling). Rhodobacter capsulatus used as outgroup. Bar indicates $0.05 \%$ sequence variance.

TABLE 5 | Effect of temperature on four test indices of biosurfactant production from strain 3B-2.

\begin{tabular}{|c|c|c|c|c|c|}
\hline Temperature $\left({ }^{\circ} \mathrm{C}\right)$ & Biomass $\left(O D_{600}\right)$ & Protein concentration $(\mathrm{g} / \mathrm{L})$ & Surface tension $(\mathrm{mN} / \mathrm{m})$ & Diameter of clear zone $(\mathrm{cm})$ & Overall weight \\
\hline 25 & 0.72 & 2.72 & 45.0 & 4.25 & 0.1587 \\
\hline 28 & 0.62 & 2.90 & 34.6 & 6.50 & 0.4998 \\
\hline 31 & 0.65 & 2.47 & 41.3 & 5.75 & 0.2217 \\
\hline 34 & 0.55 & 1.82 & 47.0 & 4.25 & 0.0478 \\
\hline 37 & 0.55 & 2.00 & 51.1 & 5.00 & 0.0720 \\
\hline$\lambda_{\max }$ & 5.2623 & 5.1926 & 5.2198 & 5.2157 & 5.21728 \\
\hline $\mathrm{Cl}$ & 0.0656 & 0.0481 & 0.0549 & 0.0539 & 0.05432 \\
\hline$R l$ & 1.12 & 1.12 & 1.12 & 1.12 & 1.12 \\
\hline$C R$ & 0.0585 & 0.043 & 0.0491 & 0.0481 & 0.0485 \\
\hline
\end{tabular}

$\lambda_{\max }=4.0458, \mathrm{Cl}=0.0153, \mathrm{Rl}=0.9, \mathrm{CR}=0.017$ ( $\lambda_{\max }$ : the maximal eigen value, $\mathrm{Cl}$ : the consistency index, $\mathrm{Rl}$ : the random index, CR: the consistency ratio).

TABLE 6 | Effect of liquid volume on four indices of biosurfactant production from strain 3B-2.

\begin{tabular}{|c|c|c|c|c|c|}
\hline Broth content (mL) & Biomass $\left(\mathrm{OD}_{600}\right)$ & Protein concentration (g/L) & Surface tension $(\mathrm{mN} / \mathrm{m})$ & Diameter of clear zone $(\mathrm{cm})$ & Overall weight \\
\hline 50 & 0.52 & 2.83 & 45.05 & 4.65 & 0.1040 \\
\hline 75 & 0.50 & 2.47 & 44.04 & 4.50 & 0.1400 \\
\hline 100 & 0.48 & 3.28 & 44.15 & 6.10 & 0.3870 \\
\hline 125 & 0.40 & 3.37 & 42.89 & 5.75 & 0.3690 \\
\hline$\lambda_{\max }$ & 4.1341 & 4.1519 & 4.1582 & 4.1263 & 4.14094 \\
\hline $\mathrm{Cl}$ & 0.0447 & 0.0506 & 0.0527 & 0.0421 & 0.04698 \\
\hline$R l$ & 0.9 & 0.9 & 0.9 & 0.9 & 0.9 \\
\hline$C R$ & 0.0497 & 0.0563 & 0.0586 & 0.0468 & 0.0522 \\
\hline
\end{tabular}

$\lambda_{\max }=4.0458, \mathrm{Cl}=0.0153, \mathrm{Rl}=0.9, \mathrm{CR}=0.017$ ( $\lambda_{\max }$ : the maximal eigen value, $\mathrm{Cl}$ : the consistency index, $\mathrm{Rl}$ : the random index, $\mathrm{CR}$ : the consistency ratio).

possibly increased energy consumption and decreased bacterial growth, negatively affecting biosurfactant production. Thus, $28^{\circ} \mathrm{C}$ was selected for fermentation production of biosurfactant from this bacterium.

The changes in biosurfactant production from strain 3B-2 with different liquid volumes, 50, 75, 100, and $125 \mathrm{~mL}$ were shown in Table 6. Optimization of liquid volume was performed by the AHP based on measurements of the four test indices. In this test, the goal was the optimal liquid volume; the alternatives were different liquid volumes. The $\lambda_{\max }$ values of the alternatives to the criteria were $4.13,4.15,4.16$, and $4.13(C R=0.0497$, $0.0563,0.0586$, and 0.0468 , respectively). Comparative matrices were built with the biomass, the protein concentration (Figure 3), the surface tension, and the diameter of clear zone to the optimal liquid volume as $1,2,3$, and 4 ; the $\lambda_{\max }$ value of the criteria to the goal was $4.05(C R=0.017)$; the individual weights of the four criteria to the goal were $0.1,0.18,0.29$, and 0.43 , respectively. The $\lambda_{\max }$ value of the alternatives to the goal was $4.14(C R=0.0522)$. All these $C R$ values were less than 0.1 and thus passed the consistency test. The obtained $\lambda_{\max }$ values 


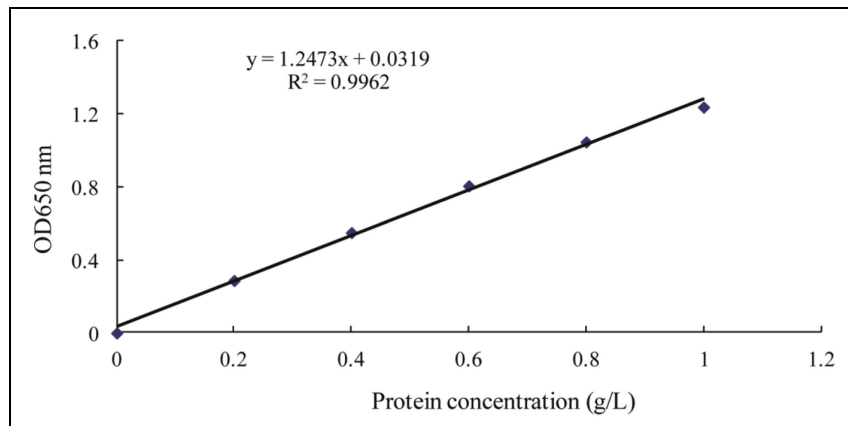

FIGURE 3 | Standard curve for determination of protein by Lowry's method (Lowry et al., 1951). OD $_{650}$ for optical density at $650 \mathrm{~nm}$ wavelength.

represent the weights of individual indices from which the overall weight could be obtained. According to the overall weight, the four test indices were highest with the liquid volume of $100 \mathrm{~mL}$. Liquid volume above or below the optimal level had a negative effect on biosurfactant production from 3B-2 (Table 6).

The effect of inoculation amount on four test indices of biosurfactant production from strain 3B-2 was presented in Table 7. In this test, the goal was the optimal inoculation amount; the alternatives were different inoculation amounts. The $\lambda_{\max }$ values of the alternatives to the criteria were $4.15,4.14,4.09$, and 4.04 ( $C R=0.0573,0.0502,0.0338$, and 0.0154 , respectively). The $\lambda_{\max }$ value of the criteria to the goal was $4.05(C R=0.017)$, and that of the alternatives to the goal was $4.08(C R=0.0311)$. These $C R$ values were less than 0.1 and passed the consistency test. The obtained $\lambda_{\max }$ values were taken as the weights of the test indices to obtain their overall weight. Results showed that within the range tested $(4,6,8$, and $10 \%)$, the highest production of biosurfactant occurred with $4 \%$ inoculation amount. A larger or smaller amount of inoculation was not favorable for biosurfactant production from strain 3B-2 (Table 7).

\section{Effect of Carbon and Nitrogen Sources}

Biosurfactant-producing bacteria generally require large amounts of oxygen (Grishchenkov et al., 2000). Since oil substrates have low capacity to dissolve oxygen, water-soluble substrates are commonly used as the carbon source to facilitate oxygen dissolution. However, some non-saccharide water-soluble substrates (e.g., ethanol) are known to inhibit the fermentative production of biosurfactants (Busscher et al., 1997). In this study, different carbon sources exhibited varying effects on the production of biosurfactant from strain 3B-2 (Table 8).

The formation of clear zone on oil surface is a unique feature of surfactants, which, together with surface tension, provides an indicator to evaluate the performance of biosurfactant-producing bacteria (Youssef et al., 2004). Strain 3B-2 formed no clear zone when grown on sucrose or glucose. That is, this bacterium did not produce biosurfactant when utilizing sucrose or glucose as carbon source. The clear zone was obvious in bacterial culture

TABLE 7 | Effect of inoculation size on four test indices of biosurfactant production from strain 3B-2.

\begin{tabular}{|c|c|c|c|c|c|}
\hline Inoculum size (\%) & Biomass $\left(\mathrm{OD}_{600}\right)$ & Protein concentration (g/L) & Surface tension $(\mathrm{mN} / \mathrm{m})$ & Diameter of clear zone $(\mathrm{cm})$ & Overall weight \\
\hline 4 & 0.60 & 2.71 & 38.25 & 7.00 & 0.4999 \\
\hline 6 & 0.61 & 2.58 & 36.30 & 6.00 & 0.3269 \\
\hline 8 & 0.54 & 2.47 & 38.65 & 6.00 & 0.0935 \\
\hline 10 & 0.46 & 2.13 & 38.98 & 6.15 & 0.0798 \\
\hline$\lambda \max$ & 4.1547 & 4.1354 & 4.0912 & 4.0417 & 4.08397 \\
\hline $\mathrm{Cl}$ & 0.0516 & 0.0451 & 0.0304 & 0.0139 & 0.02799 \\
\hline$R /$ & 0.9 & 0.9 & 0.9 & 0.9 & 0.9 \\
\hline$C R$ & 0.0573 & 0.0502 & 0.0338 & 0.0154 & 0.0311 \\
\hline
\end{tabular}

$\lambda_{\max }=4.0458, \mathrm{Cl}=0.0153, \mathrm{Rl}=0.9, \mathrm{CR}=0.017$ ( $\lambda_{\text {max }}$ : the maximal eigen value, $\mathrm{Cl}$ : the consistency index, $R \mathrm{l}$ : the random index, $\mathrm{CR}$ : the consistency ratio).

TABLE 8 | Effect of carbon sources on four test indices of biosurfactant production from strain 3B-2.

\begin{tabular}{|c|c|c|c|c|c|}
\hline Carbon source & Biomass $\left(O D_{600}\right)$ & Protein concentration (g/L) & Surface tension $(\mathrm{mN} / \mathrm{m})$ & Diameter of clear zone $(\mathrm{cm})$ & Overall weight \\
\hline Blank & 0.85 & 4.23 & 35.28 & 5.50 & 0.2081 \\
\hline Maltose & 1.13 & 5.66 & 42.44 & 6.55 & 0.1674 \\
\hline Lactose & 0.86 & 4.30 & 32.40 & 6.48 & 0.2917 \\
\hline Sucrose & 0.35 & 1.75 & 39.08 & 0.00 & 0.0506 \\
\hline Xylose & 1.10 & 5.49 & 42.95 & 7.30 & 0.2445 \\
\hline Glucose & 0.40 & 2.00 & 40.98 & 0.00 & 0.0378 \\
\hline$\lambda_{\max }$ & 4.1125 & 4.0624 & 4.189 & 4.0897 & 6.154 \\
\hline $\mathrm{Cl}$ & 0.0532 & 0.0217 & 0.0402 & 0.0235 & 0.030876 \\
\hline$R I$ & 1.24 & 1.24 & 1.24 & 1.24 & 1.24 \\
\hline$C R$ & 0.0429 & 0.0175 & 0.0324 & 0.0235 & 0.0249 \\
\hline
\end{tabular}

$\lambda_{\max }=4.0459, \mathrm{Cl}=0.0153, \mathrm{Rl}=0.9, \mathrm{CR}=0.0170$ ( $\lambda_{\max }$ : the maximal eigen value, $\mathrm{Cl}$ : the consistency index, $\mathrm{Rl}$ : the random index, $\mathrm{CR}$ : the consistency ratio). 
TABLE 9 | Effect of nitrogen sources on four test indices of biosurfactant production from strain 3B-2.

\begin{tabular}{|c|c|c|c|c|c|}
\hline Nitrogen sources & Biomass $\left(\mathrm{OD}_{600}\right)$ & Protein concentration (g/L) & Surface tension $(\mathrm{mN} / \mathrm{m})$ & Diameter of clear zone (cm) & Overall weight \\
\hline Peptone & 0.47 & 3.72 & 36.43 & 6.00 & 0.1987 \\
\hline Beef extract & 0.38 & 3.19 & 39.40 & 5.44 & 0.1400 \\
\hline Yeast extraction & 0.60 & 3.82 & 31.00 & 5.55 & 0.2213 \\
\hline Soybean meal & 0.47 & 6.55 & 31.09 & 3.00 & 0.1957 \\
\hline Corn meal & 0.14 & 0.13 & 39.44 & 0.00 & 0.0324 \\
\hline$\left(\mathrm{NH}_{4}\right)_{2} \mathrm{SO}_{4}$ & 0.05 & 0.16 & 34.33 & 0.00 & 0.0497 \\
\hline $\mathrm{NH}_{4} \mathrm{NO}_{3}$ & 0.05 & 0.14 & 34.94 & 0.00 & 0.0469 \\
\hline $\mathrm{NH}_{4} \mathrm{Cl}$ & 0.05 & 0.04 & 43.14 & 0.00 & 0.0251 \\
\hline $\mathrm{NaNO}_{3}$ & 0.09 & 0.42 & 46.30 & 0.00 & 0.0243 \\
\hline Urea & 0.10 & 0.39 & 32.47 & 0.00 & 0.0659 \\
\hline$\lambda_{\max }$ & 9.1466 & 9.4254 & 9.3003 & 9.464 & 10.438 \\
\hline $\mathrm{Cl}$ & 0.0183 & 0.0532 & 0.0375 & 0.058 & 0.0487 \\
\hline$R I$ & 1.49 & 1.49 & 1.49 & 1.49 & 1.49 \\
\hline$C R$ & 0.0126 & 0.0367 & 0.0259 & 0.04 & 0.0327 \\
\hline
\end{tabular}

$\lambda_{\max }=4.0458, \mathrm{Cl}=0.0153, \mathrm{Rl}=0.9, \mathrm{CR}=0.017$ ( $\lambda_{\text {max }}$ : the maximal eigen value, $\mathrm{Cl}$ : the consistency index, $R \mathrm{l}$ : the random index, $\mathrm{CR}$ : the consistency ratio).

TABLE 10 | Effect of salinity concentration on four test indices of biosurfactant production from strain $3 B-2$.

\begin{tabular}{|c|c|c|c|c|c|}
\hline $\mathrm{NaCl}(\%)$ & Biomass $\left(O D_{600}\right)$ & Protein concentration (g/L) & Surface tension $(\mathrm{mN} / \mathrm{m})$ & Diameter clear zone (cm) & Overall weight \\
\hline 0 & 0.06 & 0.00 & 48.00 & 0.00 & 0.0276 \\
\hline 0.5 & 0.35 & 2.62 & 44.07 & 5.65 & 0.2139 \\
\hline 1 & 0.46 & 3.88 & 45.22 & 3.75 & 0.1226 \\
\hline 1.5 & 0.56 & 3.83 & 42.27 & 4.50 & 0.1758 \\
\hline 2 & 0.60 & 3.97 & 37.68 & 4.70 & 0.2337 \\
\hline 3 & 0.68 & 4.01 & 34.57 & 0.00 & 0.2265 \\
\hline$\lambda_{\max }$ & 6.1873 & 6.104 & 6.315 & 6.1497 & 6.1922 \\
\hline $\mathrm{Cl}$ & 0.0375 & 0.0208 & 0.063 & 0.0299 & 0.03844 \\
\hline$R I$ & 1.24 & 1.24 & 1.24 & 1.24 & 1.24 \\
\hline$C R$ & 0.0302 & 0.0168 & 0.0508 & 0.02241 & 0.031 \\
\hline
\end{tabular}

$\lambda_{\max }=4.0458, \mathrm{Cl}=0.0153, \mathrm{Rl}=0.9, \mathrm{CR}=0.017$ ( $\lambda_{\max }$ : the maximal eigen value, $\mathrm{Cl}$ : the consistency index, $\mathrm{Rl}$ : the random index, CR: the consistency ratio).

TABLE 11 | Effect of ion on four test indices of biosurfactant production from strain 3B-2.

\begin{tabular}{|c|c|c|c|c|c|}
\hline lons & Biomass $\left(O D_{600}\right)$ & Protein concentration (g/L) & Surface tension $(\mathrm{mN} / \mathrm{m})$ & Diameter of clear zone $(\mathrm{cm})$ & Overall weight \\
\hline Blank & 0.59 & 3.71 & 37.55 & 6.00 & 0.1666 \\
\hline $\mathrm{ZnSO}_{4}$ & 0.33 & 2.87 & 32.55 & 5.25 & 0.0715 \\
\hline $\mathrm{Na}_{2} \mathrm{HPO}_{4}$ & 0.66 & 3.70 & 29.18 & 5.95 & 0.2577 \\
\hline $\mathrm{CaCl}_{2}$ & 0.60 & 3.81 & 36.00 & 5.45 & 0.1149 \\
\hline $\mathrm{BaCl}_{2}$ & 0.60 & 3.61 & 41.85 & 5.40 & 0.0752 \\
\hline $\mathrm{CuSO}_{4}$ & 0.32 & 2.76 & 32.43 & 4.50 & 0.0549 \\
\hline $\mathrm{MgSO}_{4}$ & 0.59 & 3.47 & 33.98 & 4.25 & 0.0555 \\
\hline $\mathrm{MnSO}_{4}$ & 0.62 & 3.49 & 34.16 & 5.55 & 0.1004 \\
\hline $\mathrm{FeCl}_{3}$ & 0.60 & 3.37 & 33.17 & 5.50 & 0.1034 \\
\hline$\lambda_{\max }$ & 9.4254 & 9.3003 & 9.464 & 9.464 & 9.379 \\
\hline $\mathrm{Cl}$ & 0.0183 & 0.0532 & 0.0375 & 0.058 & 0.0474 \\
\hline$R l$ & 1.45 & 1.45 & 1.45 & 1.45 & 1.45 \\
\hline$C R$ & 0.0126 & 0.0367 & 0.0259 & 0.04 & 0.0327 \\
\hline
\end{tabular}

$\lambda_{\max }=4.0458, \mathrm{Cl}=0.0153, \mathrm{Rl}=0.9, \mathrm{CR}=0.017$ ( $\lambda_{\max }$ : the maximal eigen value, $\mathrm{Cl}$ : the consistency index, $R \mathrm{l}$ : the random index, $C R:$ the consistency ratio).

with maltose, lactose, and xylose as carbon source. Among these, maltose and xylose supported the production of biosurfactant with higher surface tension.
Meanwhile, the four test indices were measured and the optimization of carbon resources was performed using the AHP. The goal was the optimal carbon source; the alternatives were 
TABLE 12 | Analysis of variance (ANOVA) for a response surface quadratic model for biosurfactant production of strain 3B-2.

\begin{tabular}{|c|c|c|c|c|c|c|}
\hline Source & Sum of squares & df & Mean square & $\boldsymbol{F}$ & $p$ (prob. > F) & Significance \\
\hline Model & 4.46E-03 & 9 & 4.95E-04 & 35.35 & $<0.0001$ & $* *$ \\
\hline$X_{1}$-Lactose & 1.72E-05 & 1 & 1.72E-05 & 1.23 & 0.2937 & \\
\hline$X_{2}$-Yeast extract & $3.28 \mathrm{E}-03$ & 1 & $3.28 \mathrm{E}-03$ & 233.93 & $<0.0001$ & $* *$ \\
\hline$X_{3}-\mathrm{NaCl}$ & 5.46E-04 & 1 & 5.46E-04 & 38.93 & $<0.0001$ & $* *$ \\
\hline$x_{1} x_{2}$ & $5.15 E-05$ & 1 & 5.15E-05 & 3.68 & 0.0842 & \\
\hline$x_{1} x_{3}$ & $2.57 \mathrm{E}-04$ & 1 & $2.57 E-04$ & 18.31 & 0.0016 & $*$ \\
\hline$x_{2} x_{3}$ & 8.52E-05 & 1 & 8.52E-05 & 6.08 & 0.0334 & $*$ \\
\hline$x_{12}$ & $3.26 \mathrm{E}-07$ & 1 & $3.26 \mathrm{E}-07$ & 0.023 & 0.8819 & \\
\hline$x_{22}$ & 2.23E-04 & 1 & $2.23 E-04$ & 15.91 & 0.0026 & $*$ \\
\hline$x_{32}$ & $3.16 \mathrm{E}-06$ & 1 & $3.16 \mathrm{E}-06$ & 0.23 & 0.6449 & \\
\hline Residual & $1.40 \mathrm{E}-04$ & 10 & 1.40E-05 & & & \\
\hline Lack of fit & $1.29 E-04$ & 5 & $2.57 \mathrm{E}-05$ & 11.15 & 0.0096 & $* *$ \\
\hline Pure error & 1.15E-05 & 5 & 2.31E-06 & & & \\
\hline Cor total & 4.60E-03 & 19 & & & & \\
\hline$R^{2}=0.9695$ & $\mathrm{R}_{\mathrm{adj}}{ }^{2}=0.9421$ & & & & & \\
\hline
\end{tabular}

$* p<0.05$ (significant); ** $p 0.01$ (highly significant).

A

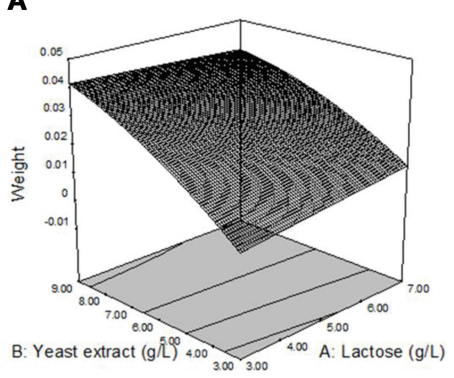

B

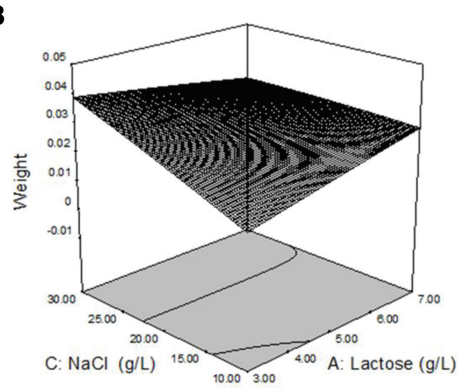

C

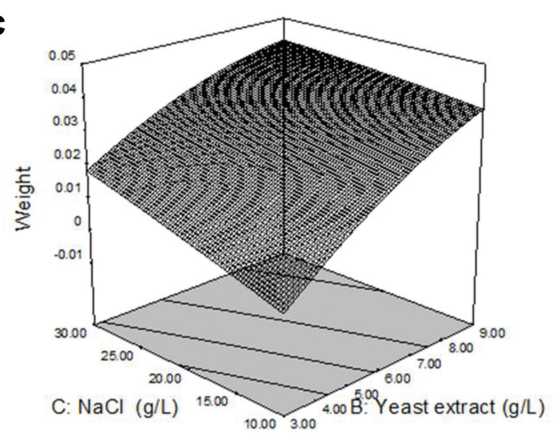

FIGURE 4 | Response surface plots of biosurfactant production from strain 3B-2. (A) Interactive effect of lactose and yeast extract with $20 \mathrm{~g} / \mathrm{L} \mathrm{NaCl}$; (B) Interactive effect of lactose and $\mathrm{NaCl}$ with $0.6 \%$ yeast; (C) Interactive effect of yeast extract and $\mathrm{NaCl}$ with $0.5 \%$ lactose.

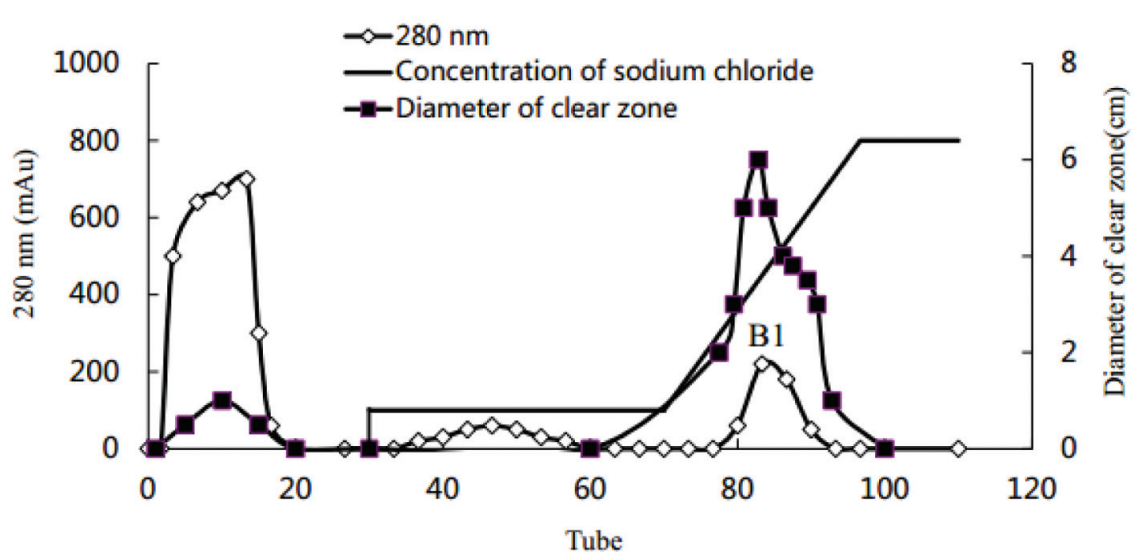

FIGURE 5 | Purification of crude biosurfactant from strain 3B-2 by DEAE-FF column chromatography.

different carbon sources. The $\lambda_{\max }$ values of the alternatives to the criteria were $4.11,4.06,4.19$, and $4.09(C R=0.0429,0.0175$, 0.0324 , and 0.0235 , respectively). The $\lambda_{\max }$ value of the criteria to the goal was $4.05(C R=0.017)$, and that of the alternatives to the goal was $6.15(C R=0.0249)$. The $C R$ values were all less than 0.1 and thus passed the consistency test. The obtained 


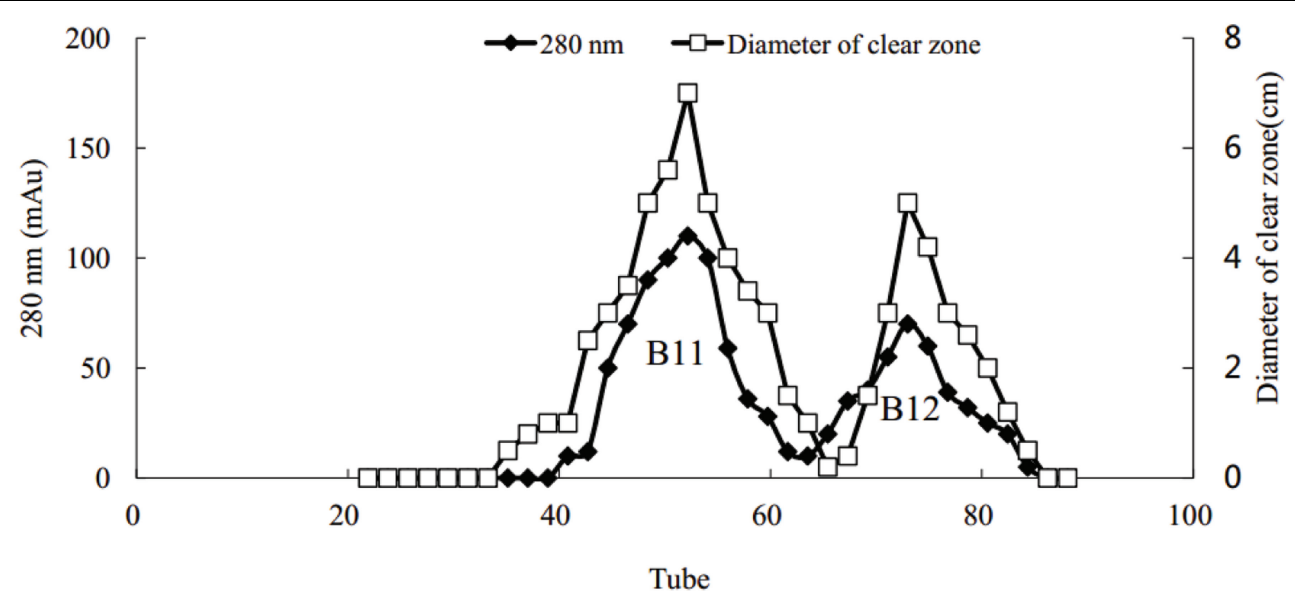

FIGURE 6 | Purification of biosurfactant fraction B1 from strain 3B-2 by Sephacryl S-100 column chromatography.

$\lambda_{\max }$ values were taken as weights of test indices to obtain their overall weight. The results showed that the four test indices were highest with lactose as carbon source. Namely, lactose was the optimal carbon source for production of biosurfactant from strain 3B-2.

The synthesis of biosurfactants is closely related to the metabolism of nitrogen resources. Meanwhile, nitrogen resources provide raw materials to produce the protoplasm and other cellular structures. Thus, nitrogen resources have a critical role in microbial growth and biosurfactant production. Table 9 shows that the organic nitrogen sources were more conducive to bacterial growth than the inorganic nitrogen sources tested. Higher oil displacement efficiency and surface tension were obtained with organic nitrogen sources consistently. These results demonstrated that strain $3 \mathrm{~B}-2$ preferentially utilized organic nitrogen sources to produce biosurfactant, with lower production from inorganic nitrogen sources.

The AHP was used to determine the optimal nitrogen source for biosurfactant production from strain $3 \mathrm{~B}-2$. In this test, the goal was the optimal nitrogen source; the alternatives were different nitrogen sources. The $\lambda_{\max }$ values of the alternatives to the criteria were $9.15,9.42,9.30$, and $9.46(C R=0.0126,0.0367$, 0.0259 , and 0.0400 , respectively). The $\lambda_{\max }$ value of the criteria to the goal was $4.05(C R=0.017)$ and that of the alternatives to the goal was $10.44(C R=0.0327)$. The $C R$ values were all less than 0.1 and thus passed the consistency test. The obtained $\lambda_{\text {max }}$ values were taken as the weights of test indices, from which the overall weight was obtained. The highest production of biosurfactant from strain 3B-2 was obtained using yeast extract as nitrogen source (Table 9).

\section{Effect of Salinity and lons}

The osmotic pressure of culture solution increases greatly with the increase of $\mathrm{NaCl}$ concentration in the medium (Greenway and Osmond, 1972). Microorganisms generally grow well in isotonic solution. Under hypotonic conditions, a large number of water molecules in solution will penetrate into the microbial cells, leading to swelling and rupture; under hypertonic condition, cells will undergo plasmolysis (Marquis, 1968). Table 10 shows that in the absence of $\mathrm{NaCl}$, strain 3B-2 almost had no growth and its biomass was substantially lower than that in other groups with $\mathrm{NaCl}$. The poor growth led to a low production of biosurfactant from the bacterium. When $30 \mathrm{~g} / \mathrm{L} \mathrm{NaCl}$ was supplied, the diameter of clear zone was zero, and the high salinity might negatively affect the surface tension of biosurfactant produced.

In this test, the goal was the optimal $\mathrm{NaCl}$ concentration; the alternatives were different $\mathrm{NaCl}$ concentrations. The $\lambda_{\max }$ values of the alternatives to the criteria were $6.19,6.10,6.32$, and 6.15 ( $C R=0.0302,0.0168,0.0508$, and 0.0224 , respectively). The $\lambda_{\max }$ value of the criteria to the goal was $4.05(C R=0.017)$ and that of the alternatives to the goal was $6.19(C R=0.031)$. All the above $C R$ values were less than 0.1 and thus passed the consistency test. The obtained $\lambda_{\max }$ values, i.e., the weights of test indices, were summed up to obtain the overall weight of the four test indices. According to the results, $20 \mathrm{~g} / \mathrm{L}$ was selected as the optimal $\mathrm{NaCl}$ concentration for biosurfactant production from strain 3B-2.

Trace ions are associated with biosurfactant synthesis and serve as the coenzyme of key enzymes involved in the synthetic process. A lack of certain ion(s) or an improper proportional relation of these ions will destroy the entire biosurfactant synthesis system. Table 11 shows that the majority of the ions tested had an inhibitory effect on biosurfactant production from strain 3B-2. An exception was that $\mathrm{Na}_{2} \mathrm{HPO}_{4}$ to some extent increased biosurfactant production from the bacterium.

In this test, the goal was the optimal ion; the alternatives were different $\mathrm{NaCl}$ concentrations. The $\lambda_{\max }$ values of the alternatives to the criteria were $9.43,9.30,9.46$, and $9.46(C R=0.0126,0.0367$, 0.0259 , and 0.04 , respectively). The $\lambda_{\max }$ value of the criteria to the goal was $4.05(C R=0.017)$ and that of the alternatives to the goal was $9.38(C R=0.0327)$. All the above $C R$ values were less than 0.1 and thus passed the consistency test. According to the overall weight of the $\lambda_{\max }$ values (e.g., weights), $\mathrm{Na}_{2} \mathrm{HPO}_{4}$ was determined to be the optimal ion species biosurfactant production from strain 3B-2. 


\section{Optimization of Culture Conditions by CCD}

According to the results of the single-factor experiments, lactose, yeast extract, and $\mathrm{NaCl}$ were selected as the primary factors to improve biosurfactant production from 3B-2. The experimental design and results are shown in Table 4 . The four test indices including the biomass, protein concentration, surface tension, and diameter of clear zone were normalized. The lower the surface tension is, the higher the surface activity. Thus, surface tension was set to -1 ; the other three indices were set to 1 . The overall weight of the actual values was obtained from the weights of individual indices presented in Section "Effect of Physical Parameters.”

\section{Regression equation and significance analysis}

The results of ANOVA analysis for a quadratic response surface model of biosurfactant production are presented in Table 12 . Model factors $X_{2}, X_{3}, X_{1} X_{3}$, and $X_{22}$ showed extremely significant effects on biosurfactant production from strain 3B-2 $(p<0.01)$. Additionally, an interaction term, $X_{2} X_{3}$, significantly affected biosurfactant production from the bacterium $(0.01<p<0.05)$. These results indicated that yeast extract and $\mathrm{NaCl}$ concentration had the greatest impact on biosurfactant production from 3B-2, while lactose had the least effect. The $F$-value was 35.35 , showing the statistical significance of the model. The effect from other interfering factors on this model was only $0.01 \%$.

The experimental data were fitted by stepwise regression using Design Expert 8.0. A multivariate quadratic regression model was obtained: $Y=-0.090205+9.13708 E-003 X_{1}+0.014698 X_{2}$ $+2.88754 E-003 X_{3}-4.22917 E-004 X_{1} X_{2}-2.83125 E-$ $004 X_{1} X_{3}-1.08750 E-004 X_{2} X_{3}-3.75750 E-005 X_{12}-$ $4.37036 E-004 X_{22}-4.68498 E-006 X_{32}$, wherein $Y$ is the predicted value of the weight of biosurfactant, and $X_{1}$ to $X_{3}$ are lactose, yeast extract, and $\mathrm{NaCl}$, respectively.

For a good statistical model, there is $R^{2}=0-1.0$. A $R^{2}$ value closer to 0 is indicative a better model and the actual value closer to the predicted value (Reddy et al., 2008). The regression equation obtained by ANOVA showed that the established model had $R^{2}=0.9695(p<0.0001)$. This result indicated that the experimental values of the weight of biosurfactant well agreed with the regression value of the model. Additionally, the model showed high statistical significance. The correction coefficient was: $R^{2}$ adj $=0.9421$; that is, the model could explain $94.21 \%$ of variation in the response value. The prediction coefficient was: $R^{2}$ pre $=0.7826$; the lack of fit items was not significant $(F=11.15, p=0.096>0.05)$, indicating that the model could fully reflect the actual situation. Collectively, the above data demonstrated good fit of the model. Hence, the proposed model can be used to analyze and predict the effects of lactose, yeast extract and $\mathrm{NaCl}$ on biosurfactant production from strain 3B-2 strain.

\section{Response surface analysis}

Response surface plots of biosurfactant production from strain 3B-2 (Figure 4) were generated from the quadratic regression equation. The shape of the response surface was analyze to evaluate the interactive and individual effects of relevant factors on the response value. The contour of the model was nearly

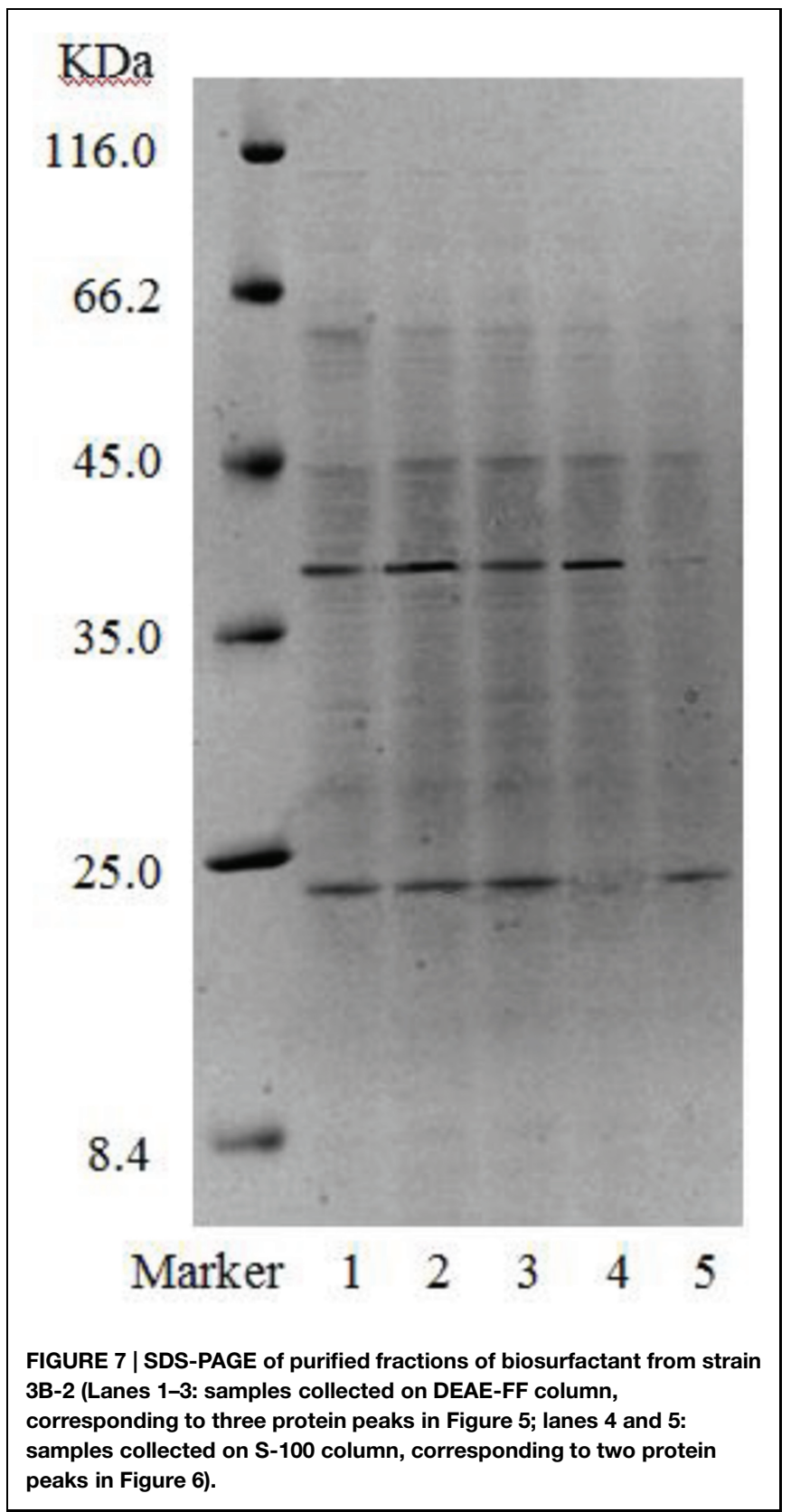

horizontal, rather than elliptical, possibly because the interactive effect of relevant factors was relatively weak (Reddy et al., 2008).

In the presence of $20 \mathrm{~g} / \mathrm{L} \mathrm{NaCl}$, the production of biosurfactant increased with increasing concentrations of lactose and yeast extract, and a greater increase in biosurfactant production was observed with yeast extract (Figure 4A). In the presence of $6 \mathrm{~g} / \mathrm{L}$ yeast extract, lactose, and $\mathrm{NaCl}$ concentration changes had little effect on biosurfactant production (Figure 4B). In the presence of $5 \mathrm{~g} / \mathrm{L}$ lactose, biosurfactant production increased with increasing concentrations of $\mathrm{NaCl}$ and yeast extract, but the effect of $\mathrm{NaCl}$ concentration change on biosurfactant production was less (Figure 4C). 


\section{Purification of Crude Biosurfactant}

Using the Hiprep DEAE-FF column, protein peaks were obtained at 10,46, and 81 tube, which exhibited lower activity, no activity, and higher oil-displacement activity, respectively (Figure 5). The last eluting peak was named biosurfactant B1. SDS-PAGE analysis showed that the purity of $\mathrm{B} 1$ was relatively low. Then $\mathrm{B} 1$ was concentrated and purified by gel filtration chromatography on the Sephacryl S-100 column, which resulted in two peaks, named B11 and B12, respectively (Figure 6). Oil-displacement test data of B11 and B12 agreed with the experimental results of protein peaks Sephacryl S-100 column.

Gel electrophoresis revealed that in addition to two strong bands (i.e., B1 and B2), there were other miscellaneous protein bands in the samples collected from the DEAE-FF column (Figure 7, lanes 1-3). Clearly, the three samples were not completely purified on the DEAE-FF column. Samples collected from the Sephacryl S-100 column only showed a single clear band each (Figure 7, lanes 4 and 5), which was indicative of their high purity. The molecular weights of B11 and B12 were $\sim 40$ and $22 \mathrm{kDa}$, respectively.

\section{Conclusion}

Biosurfactant production by Marine Vibrio sp. strain 3B-2 was evaluated using RSM and AHP techniques to find the optimal composition of growth medium. Experimental results showed

\section{References}

Busscher, H. J., van Hoogmoed, C. G., Geertsema-Doornbusch, G. I., van der Kuijl-Booij, M., and van der Mei, H. C. (1997). Streptococcus thermophilus and its biosurfactants inhibit adhesion by Candida spp. on silicone rubber. Appl. Environ. Microbiol. 63, 3810-3817.

Daifullah, A. A. M., and Girgis, B. S. (2003). Impact of surface characteristics of activated carbon on adsorption of BTEX. Colloids Surf. A Physicochem. Eng. Asp. 214, 181-193. doi: 10.1016/S0927-7757(02)00392-8

Desai, J. D., and Banat, I. M. (1997). Microbial production of surfactants and their commercial potential. Microbiol. Mol. Biol. Rev. 61, 47-64.

Enticknap, J. J., Kelly, M., Peraud, O., and Hill, R. T. (2006). Characterization of a culturable alphaproteobacterial symbiont common to many marine sponges and evidence for vertical transmission via sponge larvae. Appl. Environ. Microbiol. 72, 3724-3732. doi: 10.1128/AEM.72.5.3724-373 2.2006

Espuny, M. J., Egido, S., Rodon, I., Manresa, A., and Mercadé, M. E. (1996). Nutritional requirement of a biosurfactant producing strain Rhodococcus sp. 51T7. Biotechnol. Tech. 7, 745-748. doi: 10.1007/bf00140196

Gawande, P. V., and Kamat, M. Y. (1999). Production of Aspergillus xylanase by lignocellulosic waste fermentation and its application. J. Appl. Microbiol. 87, 511-519. doi: 10.1046/j.1365-2672.1999.00843.x

Greenway, H., and Osmond, C. B. (1972). Salt responses of enzymes from species differing in salt tolerance. Plant Physiol. 49, 256-259. doi: 10.1104/pp. 49.2.256

Grishchenkov, V. G., Townsend, R. T., McDonald, T. J., Autenriethb, R. L., Bonnerb, J. S., and Boronin, A. M. (2000). Degradation of petroleum hydrocarbons by facultative anaerobic bacteria under aerobic and anaerobic conditions. Process Biochem. 35, 889-896. doi: 10.1016/S0032-9592(99) 00145-4

Hedlund, B. P., and Staley, J. T. (2001). Vibrio cyclotrophicus sp. nov., a polycyclic aromatic hydrocarbon (PAH)-degrading marine bacterium. Int. J. Syst. Evol. Microbiol. 51, 61-66. doi: 10.1099/00207713-51-1-61 that the optimal medium contained: lactose, yeast extract, sodium chloride and disodium hydrogen phosphate according to proportion mentioned above was the best solution. And the optimum growth temperature used in this manuscript was $28^{\circ} \mathrm{C}$. The results of this study indicated that biosurfactant can efficiently reduce surface and interfacial tension, and has high oil-displacement efficiency. This finding has a practical advantage because the use of this kind of biosurfactant as a means to promote the degradation of oil may result in wider application of biosurfactant in bioremediation. The features of the biosurfactant production by Marine Vibrio sp. strain 3B2 make it a promising agent for cleaning up environments contaminated with petroleum compounds. The potential of this kind of biosurfactant for bioremediation application is highly dependent on biotic and abiotic parameters, thus further studies to check its activity and ability in hydrocarbon remediation will be recommended.

\section{Acknowledgments}

This work was supported by the project of on-site sediment microbial remediation of public area of central Bohai Sea, North China Sea Branch of State Oceanic Administration (No. QDZC20150420-002), the National Natural Science Foundation of China (No. 41376138), the Hundred Talents Program of Chinese Academy of Sciences (awarded to Dr. Xiaoke Hu).

Jernelöv, A. (2010). The threats from oil spills: now, then, and in the future. Ambio 39, 353-366. doi: 10.1007/s13280-010-0085-5

Laemmli, U. K. (1970). Cleavage of structural proteins during assembly of the head of bacteriophage T4. Nature 227, 680-685. doi: 10.1038/227680a0

Lee, S. C., Lee, S. J., Kim, S. H., Park, I. H., Lee, Y. S., Chung, S. Y., et al. (2008). Characterization of new biosurfactant produced by Klebsiella sp. Y61 isolated from waste soybean oil. Bioresour. Technol. 99, 2288-2292. doi: 10.1016/j.biortech.2007.05.020

Liao, C. N. (2010). Supplier selection project using an integrated Delphi, AHP and Taguchi loss function. ProbStat Forum 3, 118-134.

Lin, M., Liu, Y. H., Chen, W. W., Wang, H., and Hu, X. K. (2014). Use of bacteriaimmobilized cotton fibers to absorb and degrade crude oil. Int. Biodeter. Biodegradation 88, 8-12. doi: 10.1016/j.ibiod.2013.11.015

Lowry, O. H., Rosebrough, N. J., Farr, A. L., and Randall, R. J. (1951). Protein measurement with the folin phenol reagent. J. Biol. Chem. 193, 265-275.

Makkar, R. S., and Cameotra, S. S. (2002). An update on the use of unconventional substrates for biosurfactant production and their new application. Appl. Microbiol. Biotechnol. 58, 428-434. doi: 10.1007/s00253-001-0924-1

Mansora, M. R., Sapuan, S. M., Zainudin, E. S., Nuraini, A. A., and Hambali, A. (2013). Hybrid natural and glass fibers reinforced polymer composites material selection using Analytical Hierarchy Process for automotive brake lever design. Mater. Des. 51, 484-492. doi: 10.1016/j.matdes.2013.04.072

Marquis, R. E. (1968). Salt-induced contraction of bacterial cell walls. J. Bacteriol. 95, 775-781.

Martinez, A., Rodriguez, M. E., York, S. W., Preston, J. F., and Inqram, L. O. (2000). Use of UV absorbance to monitor furans in dilute acid hydrolysates of biomass. Biotechnol. Prog. 16, 637-641. doi: 10.1021/bp0000508

Morikawa, M., Daido, H., Takao, T., Murata, S., Shimonishi, Y., and Imanaka, T. (1993). A new lipopeptide biosurfactant produced by Arthrobacter sp. strain MIS38. J. Bacteriol. 175, 6459-6466.

Najafi, A. R., Rahimpour, M. R., Jahanmiri, A. H., Roostaazad, R., Arabian, D., and Ghobadi, Z. (2010). Enhancing biosurfactant production from an indigenous strain of Bacillus mycoides by optimizing the growth conditions 
using a response surface methodology. Chem. Eng. J. 163, 188-194. doi: 10.1016/j.cej.2010.06.044

Noel, R. K., and George, M. G. (2005). Bergey's Manual of Systematic Bacteriology. Volume Two: The Proteobacteria, Part A Introductory Essays. Heidelberg: Springer Science \& Business Media.

Ong, S. K., Koh, T. H., and Nee, A. Y. C. (2001). Assessing the environmental impact of materials processing techniques using an analytical hierarchy process method. J. Mater. Process. Technol. 113, 424-431. doi: 10.1016/S09240136(01)00618-5

Rathore, S., Desai, P. M., Liew, C. V., Chan, L. W., and Lieng, P. W. S. (2013). Microencapsulation of microbial cells. J. Food Eng. 116, 369-381. doi: 10.1016/j.jfoodeng.2012.12.022

Ratkowsky, D. A., Olley, J., McMeekin, T. A., and Ball, A. (1982). Relationship between temperature and growth rate of bacterial cultures. J. Bacteriol. 149, 1-5.

Reddy, L. V. A., Wee, Y. J., Yun, J. S., and Ryu, H. W. (2008). Optimization of alkaline protease production by batch culture of Bacillus sp. RKY3 through Plackett-Burman and response surface methodological approaches. Bioresour. Technol. 99, 2242-2249. doi: 10.1016/j.biortech.2007.05.006

Rodrigues, L. R., Teixeira, J. A., Oliveira, R., and van der Mei, H. C. (2006). Response surface optimization of the medium components for the production of biosurfactants by probiotic bacteria. Process Biochem. 41, 1-10. doi: 10.1016/j.procbio.2005.01.030

Santos, D. K. F., Brandão, Y. B., Rufino, R. D., Luna, J. M., Salgueiro, A. A., Santos, V. A., et al. (2014). Optimization of cultural conditions for biosurfactant production from Candida lipolytica. Biocatal. Agric. Biotechnol. 3, 48-57. doi: 10.1016/j.bcab.2014.02.004

Shete, A. M., Wadhawa, G., Banat, I. M., and Chopade, B. A. (2006). Mapping of patents on bioemulsifier and biosurfactant: a review. J. Sci. Ind. Res. 65, 91-115.

Singh, M., Saini, V., Adhikari, D. K., Desai, J. D., and Sista, V. R. (1990). Production of bioemulsifier by SCP producing strain of Candida tropicalis during hydrocarbon fermentation. Biotechnol. Lett. 12, 743-746. doi: $10.1007 / \mathrm{BF} 01024732$
Singh, P., and Cameotra, S. S. (2004). Potential applications of microbial surfactants in biomedical sciences. Trends Biotechnol. 22, 142-146. doi: 10.1016/j.tibtech.2004.01.010

Toledo, F. L., Gonzalez-Lopez, J., and Calvo, C. (2008). Product on of bioemulsifier by Bacillus subtilis, Alcaligenes faecalis and Enterobacter species in liquid culture. Bioresour. Technol. 99, 8470-8475. doi: 10.1016/j.biortech.2007.08.055

Wei, W., Zheng, Z., Liu, Y., and Zhu, Z. (1998). Optimizing the culture conditions for higher inulinase production Kluyveromyces sp. Y-85 and scaling-up fermentation. J. Ferment. Bioeng. 26, 395-399. doi: 10.1016/S0922338X(99)89011-4

Xue, J., Yu, Y., Bai, Y., Wang, L., and Wu, Y. (2015). Marine oil-degrading microorganisms and biodegradation process of petroleum hydrocarbon in marine environments: a review. Curr. Microbiol. 71, 220-228. doi: 10.1007/s00284-015-0825-7

Youssef, N. H., Duncan, K. E., Nagle, D. P., Savage, K. N., Knapp, R. M., and McInerney, M. J. (2004). Comparison of methods to detect biosurfactant production by diverse microorganisms. J. Microbiol. Methods 56, 339-347. doi: 10.1016/j.mimet.2003.11.001

Zhang, X. S., Xu, D. J., Zhu, C. Y., Lundaa, T., and Kerstin, E. S. (2012). Isolation and identification of biosurfactant producing and crude oil degrading Pseudomonas aeruginosa strains. Chem. Eng. J. 209, 138-146. doi: 10.1016/j.cej.2012.07.110

Conflict of Interest Statement: The authors declare that the research was conducted in the absence of any commercial or financial relationships that could be construed as a potential conflict of interest.

Copyright (c) $2015 \mathrm{Hu}$, Wang and Wang. This is an open-access article distributed under the terms of the Creative Commons Attribution License (CC BY). The use, distribution or reproduction in other forums is permitted, provided the original author(s) or licensor are credited and that the original publication in this journal is cited, in accordance with accepted academic practice. No use, distribution or reproduction is permitted which does not comply with these terms. 